\title{
УДК 004.42
}

\section{ANALYSIS OF COMPUTER SYSTEMS FOR THE ORDERING FOREIGN LANGUAGES COURSES ABROAD АНАЛІЗ КОМП'ЮТЕРНИХ СИСТЕМ ДЛЯ ЗАМОВЛЕННЯ КУРСІВ ІНОЗЕМНИХ МОВ ЗАКОРДОНОМ}

Andriiv.I.V. / Андріїв I.B. Ivano-Frankivsk National Technical University of Oil and Gas, Ukraine, 76019, Ivano-Frankivsk, st. Karpatska, 15, Івано-Франківський Національний Технічний університет нафти і газу, Украӥна, 76019, Івано-Франківськ, вул. Карпатська, 15,

Анотація. Стаття присвячена аналізу ринку курсів іноземних мов закордоном та комп'ютерних систем, які є гравиями на вищевказаному ринку. Дослідження засновано на статистичних матеріалах $i$ роботах вітчизняних учених 3 питання сучасного функціонування та перспектив розвитку ринку. Виділені динаміка та структура ринку курсів іноземних мов закордоном. Виявлені основні приорітети розвитку та зростання ринку.

Ключові слова: навчання закордоном, курси іноземних мов, вивчення іноземної мови, комп'ютерні системи, рикок курсів іноземних мов закордоном.

Хоча зараз мільярди людей вивчають іноземну мову, лише 0,25\% 3 них виїжджають за кордон, щоб навчатися в місцевому середовищі. Це дорівнює ринку в 2,28 мільйонів студентів за кордоном на рік. Популярність англійської мови, при цьому 78\% всіх студентів, які використовують агенти(офлайн агентства для замовлення курсів) для вивчення мови, обирають курси вивчення англійської мови, у порівнянні з лише 7\% для французької мови, 6\% для німецької та 5\% для іспанських.Однак існують регіональні варіанти. Наприклад, студенти з Азії та MENA вибирають англійську мову (87\% та 86\% відповідно), тоді як студенти з Свропи та Латинської Америки демонструють більший попит на неанглійні мови, як правило, французьку або німецьку.

Мотивація вивчення іноземної мови.

Мета вивчення іноземної мови за кордоном відходить від особистих причин (веселощі, бажання вивчити мову, компонент подорожі), з погляду кар'єри (поточні або майбутні дослідження, перспективи зайнятості). Наприклад, німецька та англійська мови в основному шукаються для поточних та майбутніх досліджень (відповідно 62\% та 61\% студентів). Тим часом, росіяни, українці та китайці в основному були пов'язані 3 підвищенням зайнятості (53,6\% та 42,3\% відповідно).

Мотивація студентів для вивчення французької мови включала поєднання як особистих, так і практичних міркувань, i, нарешті, більшість студентів, як видається, зацікавлені в тому, щоб вивчати португальську та італійську мову лише для особистого задоволення.

Тенденції вивчення мови серед студентів віком до 25 років.

Як ми нещодавно спостерігали на ринку вивчення англійської мови, молоді студенти займають все більшу частку клієнтської бази (тобто 47\% всіх студентів, як повідомляють в English UK, 47\%, як повідомляють Marketing 
Ireland, i 45\%, як повідомили в Національному статистичному управлінні Мальти). У доповіді прогнозується також збільшення кількості юних студентів для інших європейських мов, а вимога вже здорова: Найбільша частка юніорів, відряджених за кордон (до 18 років), була повідомлена про курси німецької мови (35\% всіх клієнтів - юніори у 2017 р.). Французька та англійська мови супроводжувались близько, 3 середньою часткою $34 \%$ від загального обсягу агента. Іспанські також демонстрували високу частку молодших студентів (що становить $33 \%$ ).

Більшість студентів запрошують на загальноосвітні та інтенсивні курси англійської мови за кордоном, однак, серед молодшого ринку, підготовка до іспитів та літні табори є кращими. Однією з причин цього може бути те, що вивчення англійської мови впроваджується в молодшому віці та через основний навчальний план початкової та / або середньої школи в більшій кількості країн, отже молоді учні вже піддаються фундаменту англійської мови та їдуть за кордон для більш активного або цілеспрямованого використання мови.

На підставі результатів досліджень можна зробити наступні висновки:

- В продовж наступних кількох років не очікується жодних серйозних змін у термінах мовних уподобань.

- Ринок орієнтований на багатомовність.

- Мета вивчення іноземної мови за кордоном відходить від особистих причин (веселощі, бажання вивчати мову, подорожі), в напрямку кар'єри (поточні або майбутні дослідження, перспективи зайнятості).

Проаналізувавши ринок освітніх послуг 3 вивчення іноземних мов закордоном також проаналізуємо наступні веб-сайти, які $є$ гравцями на українському ринку:

1. Освітня агенція "Вивчай” (http://vyvchay.com/uk) має ряд недоліків серед яких застарілий користувацький інтерфейс та неможливість фільтрувати школи за ціною, відсутність можливості замовлення онлайн, не має можливості зробити відгук про школу, відсутній розділ з поширеними запитання для швидкого надання поширеної інформації потенційному клієнту, висока комісія школи за курс до $21 \%$ вартості.

2. Освітня агенція "Aniway" (https://anywayplus.com/ua/) має ряд таких недоліків: відсутність можливості замовлення онлайн, не має можливості зробити відгук про школу, відсутній розділ з поширеними запитання для швидкого надання поширеної інформації потенційному клієнту, висока комісія школи за курс до $21 \%$ вартості.

3. Освітня агенція “Американська англійська школа"( http://ames.org.ua/studies/abroad/language-courses-for-adults/) має такі недоліки: застарілий користувацький інтерфейс та неможливість фільтрувати школи за ціною, відсутність можливості замовлення онлайн, не має можливості зробити відгук про школу, відсутній розділ з поширеними запитання для швидкого надання поширеної інформації потенційному клієнту, висока комісія школи за курс до 21\% вартості. 


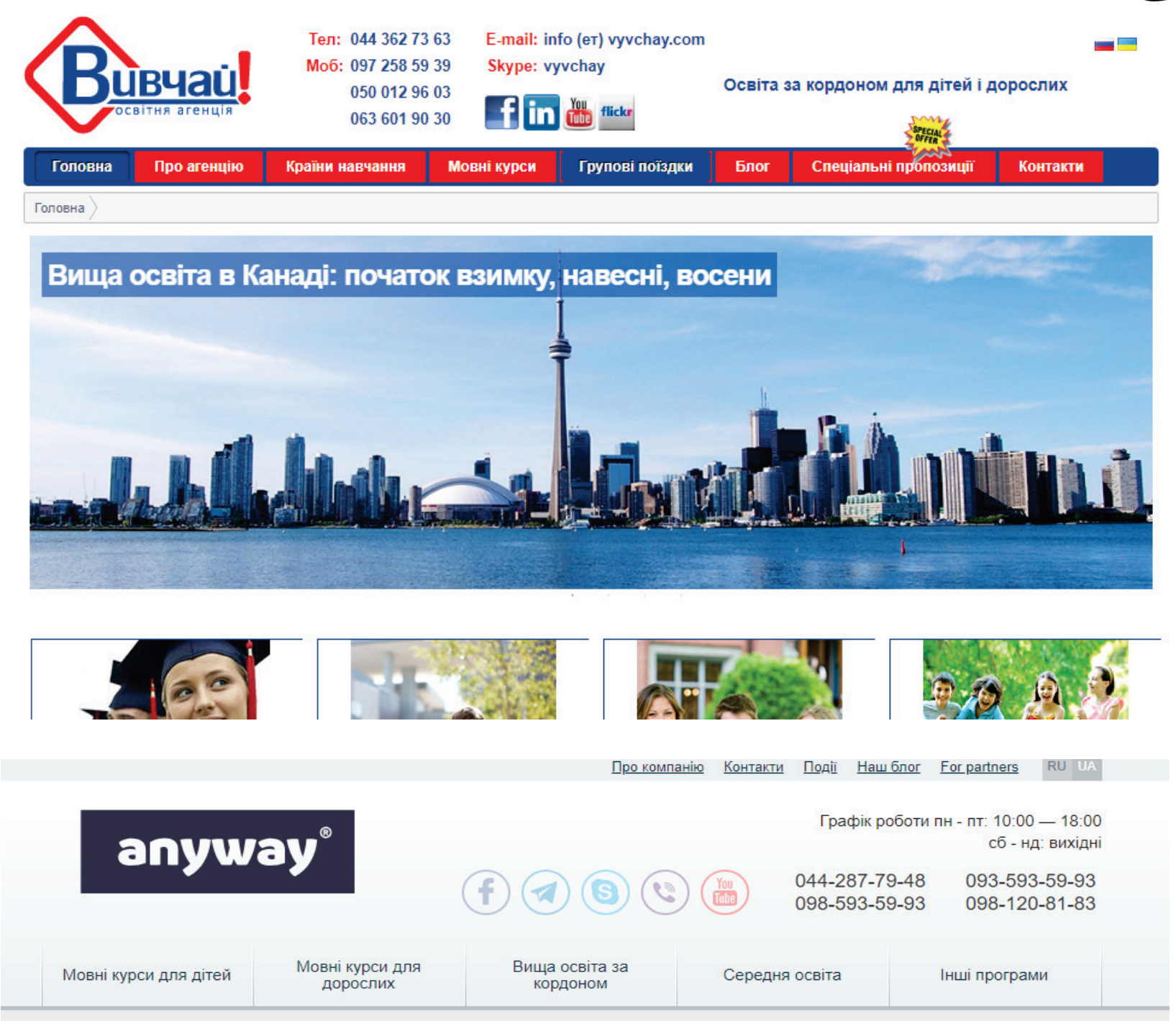

Anyway - лідер ринку освіти за кордоном
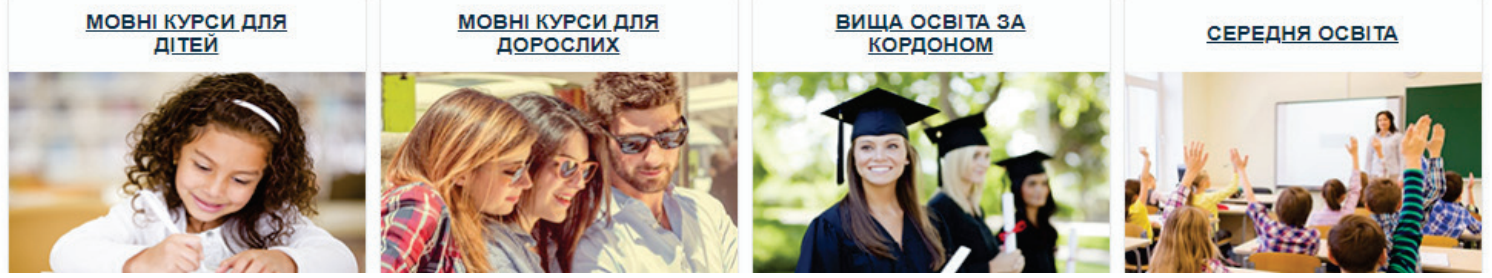

4. Освітня агенція "Карандаш" (https://karandash.ua/) має недоліків: відсутність можливості замовлення онлайн, не має можливості зробити відгук про школу, відсутній розділ з поширеними запитання для швидкого надання поширеної інформації потенційному клієнту, висока комісія школи за курс до $21 \%$ вартості.

Ринок освітніх послуг з вивчення іноземних мов закордоном має близькі тренди розвитку, спостерігається його відносна збалансованість. Він потребує сучасних та зручних у використанні веб-сайтів, які стануть у нагоді для забезпечення освітніх послуг та допоможуть зберегти зростання тенденцій,що спостерігаються на сьогоднішній день. Аналізуючи веб-сайти, які $є$ гравцями на українському ринку можна побачити ряд негативних показників, що 


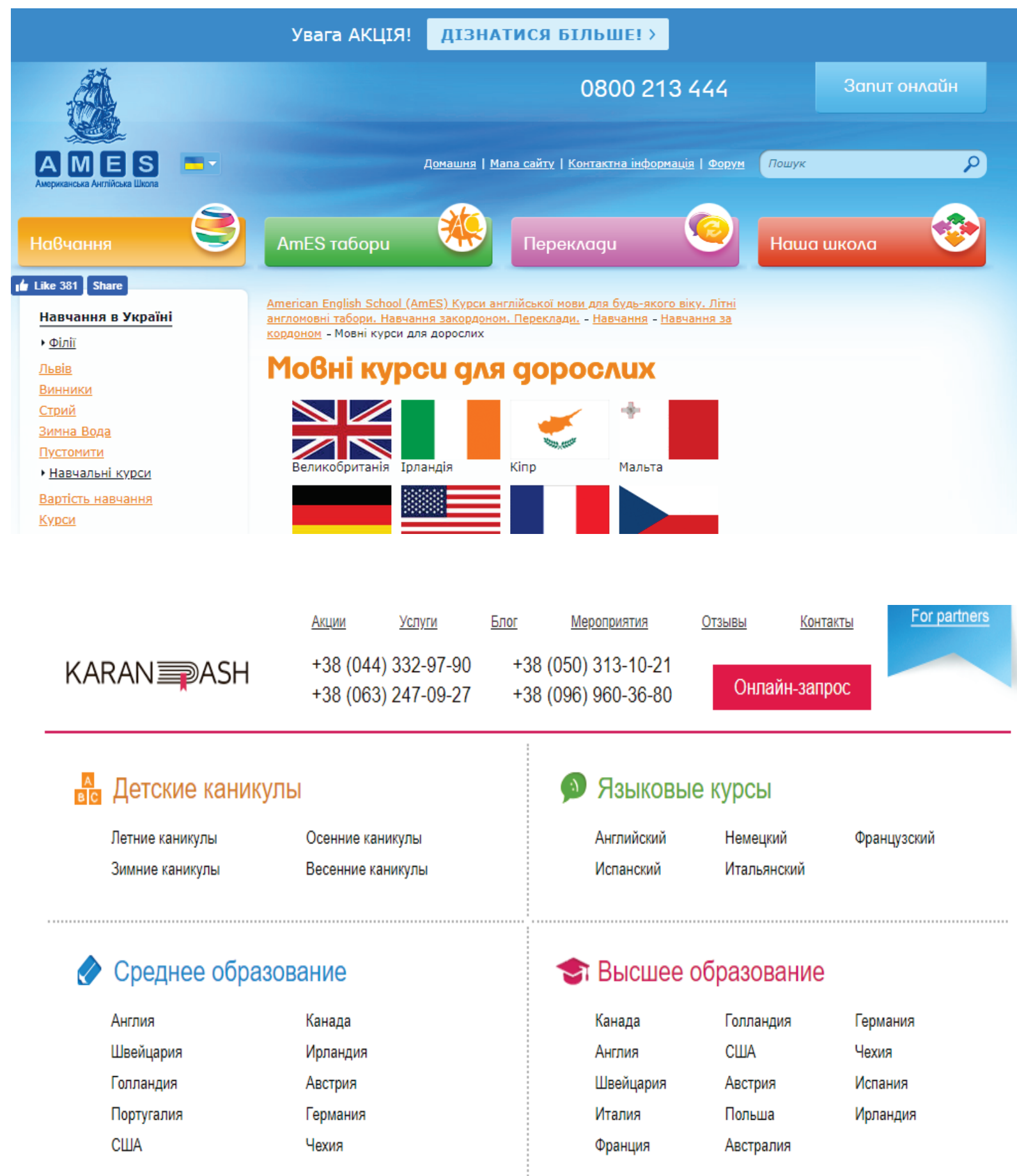

відлякують від користування такими сайтами:

- застарілий користувацький інтерфейс;

- неможливість замовлення мовного курсу онлайн;

- відсутня можливість залишити оцінку та відгук про мовний курс;

- висока комісія школи за курс до 21\% вартості

- відсутній розділ з поширеними запитаннями.

На підставі аналізу веб-сайтів освітніх послуг з вивчення іноземних мов було виявлено достатньо недоліків таких систем та свідчить про те, що наразі в Україні немає якісних та зручних веб-сайтів, які б могли забезпечувати 
швидке та зручне середовище для замовлення. Має бути розроблений веб-сайт, який виправить всі вище вказані недоліки та буде зручним для користування.

Література:

1. Державний комітет статистики України [Електронний ресурс]. - Режим доступу : http://www.ukrstat.gov.ua.

2. Trends in the Demand for Foreign Languages [Електронний ресурс]. Режим доступу :

https://www.ialc.org/fileadmin/uploads/ialc/Documents/Study_Travel_Research_Rep orts/ialc-2016-research-trends-in-demand-for-foreign-languages.pdf

Abstract. The article is devoted to the analysis of the market the ordering foreign languages courses abroad and computer systems, which are players in the above-mentioned market. The research is based on statistical materials and works of domestic scientists on the issue of modern functioning and prospects of market development. Dedicated dynamics and structure of the ordering foreign languages courses abroad market. The main priorities of development and market growth are revealed.

Key words: studying abroad, courses of foreign languages abroad, learning foreign languages abroad, computer systems, the the ordering foreign languages courses abroad market.

References

1. Derzhavnyj komitet statystyky Ukrai'ny, official website, available at: www.ukrstat.gov.ua.

2. Trends in the Demand for Foreign Languages [Electronic resource]. - Access mode :

https://www.ialc.org/fileadmin/uploads/ialc/Documents/Study_Travel_Research_Reports/ialc -2016-research-trends-in-demand-for-foreign-languages.pdf

Стаття відправлена: 09.06.2018p.

(C) Андріїв I.B. 